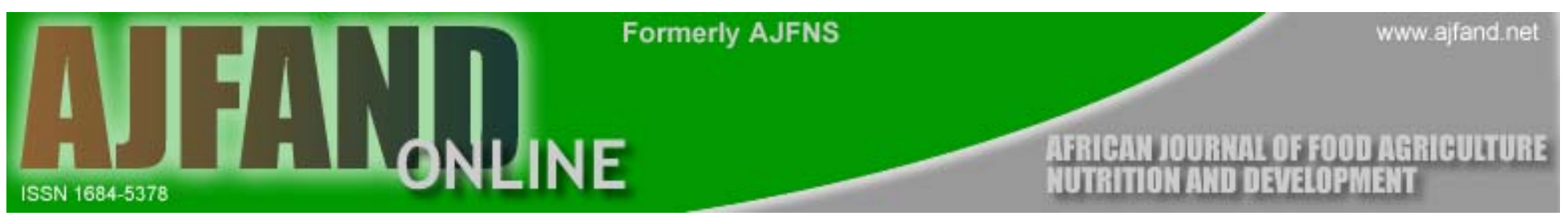

PEER REVIEWED ARTICLE No 4

\title{
APPRAISAL OF TRADITIONAL TECHNOLOGIES IN THE PROCESSING AND UTILIZATION OF MUMU; A CEREAL BASED LOCAL FOOD PRODUCT
}

\author{
Ingbian, E. $\mathrm{K}^{*}$ and Akpapunam, M.A ${ }^{1}$
}

\author{
EMMANUEL INGBIAN
}

${ }^{*}$ Corresponding Author Ingbian, E. K* (B.Sc; M.Sc; Ph.D) Lecturer I and Ag. Head: Department of Food Science and Technology University of Agriculture Makurdi. Nigeria. E-mail: ekingbian@yahoo.com Tel.: 08034487990

${ }^{1}$ Akpapunam, M.A (B.Sc; M.Sc; Ph.D) Professor and Dean: College of Food Technology, Department of Food Science and Technology, University of Agriculture, Makurdi. Nigeria. E-mail: profakpaps@yahoo.com Tel.: 08043180584 


\section{ABSTRACT}

A survey on the production practices and mode of utilization of mumu - a traditional, ready-to-eat Nigerian cereal-based food product - was conducted to be able to provide information that would be used to improve on the processing, nutritional quality and acceptability of the product. $83 \%$ of respondents indicated the use of maize as the raw material for mumu processing, while $35 \%$ also use sorghum. The procedure adopted for mumu processing varies from one processor to another. Based on pre-process operations, three procedures were identified for the production of mumu, namely; sprinkling the grains with water before roasting, steeping the grains overnight before roasting, and parboiling of the grains before roasting. The roasted grains are milled to produce a roasted meal (mumu) which is reconstituted in the ratio of 2:1 (meal: water) and consumed by both adults and children. The study indicates that of the more than $70 \%$ of mumu processors, $92 \%$ are females, mostly ( $>60 \%$ ) from the age of 36 years and above, are not well educated and therefore, ill-equipped to appreciate modern methods of food hygiene, handling and processing. The study also indicates that the traditional methods used in the processing of mumu are not standardized. Subsequently, product quality attributes such as colour, texture and flavour have not been well defined and are non-uniform. The study shows that mumu is usually reconstituted in cold water with sugar or honey added to taste. The product is usually served in the afternoon and provides an immediate source of energy as well as refreshment. Mumu as a food product has great potential, but is currently underutilized and neglected. Factors contributing to lack of consumer appeal of mumu include; inadequate hygienic practices during and after processing, low nutritional value, variable sensory quality attributes and unattractive presentation. This study presents approaches such as supplementation with oilseeds, and/or legumes and standardization of processing methods to improve on the nutritional quality and methods of processing and utilization of mumu.

Keywords: Traditional technology, processing, roasting, maize, mumu

\section{FRENCH}

\section{$R E ́ S U M E ́$}

Une étude sur les pratiques de production et le mode d'utilisation du mumu - un produit alimentaire traditionnel nigérian prêt à être mangé, qui est dérivé de céréales a été menée en vue de donner des informations qui pourraient être utilisées pour améliorer le traitement, la qualité nutritionnelle et l'acceptabilité de ce produit. Quatre-vingt-trois pour cent de personnes interrogées ont indiqué l'utilisation du maïs comme étant la matière première pour le traitement du mumu, tandis que $35 \%$ utilisent également le sorgho. La procédure adoptée pour le traitement du mumu varie 
d'une personne à l'autre engagée dans ce traitement. A partir d'opérations antérieures au traitement, trois procédures ont été identifiées pour la production du mumu: humecter les graines avec de l'eau avant de les griller, tremper les graines toute la nuit avant de les griller, et faire cuire à demi les graines avant de les griller. Les graines grillées sont moulues pour produire un repas grillé (mumu) qui est reconstitué dans la proportion de 2:1 (repas: eau) et consommé aussi bien par les adultes que par les enfants. La présente étude indique que sur plus de $70 \%$ des personnes qui traitent le mumu 92 \% sont des femmes, la majorité (> 60 \%) ayant l'âge de 36 ans et plus. Ces femmes ne sont pas très instruites; par conséquent elles sont mal équipées pour apprécier les méthodes modernes d'hygiène alimentaire exigée dans la préparation et le traitement des aliments. Cette étude indique également que les méthodes traditionnelles utilisées dans le traitement du mumu ne sont pas standardisées. Comme conséquence, les attributs de qualité des produits tels que la couleur, la texture et la saveur n'ont pas été bien définis et ne sont pas uniformes. L'étude montre que le mumu est habituellement reconstitué dans de l'eau froide en y ajoutant du sucre ou du miel pour lui donner du goût. Ce produit est généralement servi au cours de l'après-midi et il constitue une source immédiate d'énergie et de rafrâichissement. Le mumu en tant que produit alimentaire a de grandes potentialités, mais il est actuellement sous-utilisé et négligé. Les facteurs contribuant au fait que les consommateurs ne s'intéressent pas au mumu sont notamment les suivants: des pratiques hygiéniques inadéquates pendant et après le traitement, la valeur nutritive insuffisante, des attributs de qualité sensorielle variables et une présentation peu attrayante. Cette étude présente des approches telles que la fortification du mumu en lui ajoutant des graines oléagineuses, et/ou des légumineuses et la standardisation des méthodes de traitement afin d'améliorer la qualité nutritive et les méthodes de traitement et d'utilisation du mumu.

Mots-clés: Technologie traditionnelle, traitement, griller, maïs, mumu

\section{INTRODUCTION}

Мити is a traditional, ready-to-eat, Nigerian cereal-based food product prepared mostly from equal amounts of maize, sorghum and millet. This is because their physico-chemical properties are generally similar and this factor makes it technically feasible for any of the cereals to replace either of the remaining two in food systems [1]. The major unit operations in the processing of mumu are roasting of the grains and milling of the roasted 
grains into a meal. However, before the roasting process, certain preliminary operations such as cleaning (sorting, winnowing, washing), sprinkling with water, steeping the grains and parboiling are carried out. There are variations in the use of these preliminary operations in the procedure adopted by individual processors for traditional methods of mumu processing. Apart from the major operations of roasting the grains and milling into a meal, preliminary operations such as parboiling, steeping and sprinkling with water are optional. Based on this variation, three procedures have been identified for traditional тити processing. These include:

(i) Sprinkling - The grains are winnowed to remove chaff and sorted to remove visible stones and other foreign materials. They are then sprinkled with a little amount of water. This is followed by roasting and milling.

(ii) Steeping - The grains are winnowed, sorted and steeped in water overnight. The steeped grains are dewatered to remove the steep water and allowed to drain for about 10 - 15 minutes. This is followed by roasting and milling.

(iii) Parboiling - This involves preliminary cleaning and washing of the grains followed by cooking of the grains in water for about one hour to soften the grains. The pre-cooked grains are then roasted and milled.

Following processing, the roasted meal is reconstituted in the ratio of 2:1 (meal: water) with sugar or honey added to taste. The reconstituted meal is consumed by both adults and children.

Mumu as a food product has been underutilized and neglected [2]. Information regarding its processing and utilization are also scarce. Presently, the processing and consumption of mumu is village based. Like most traditional food products, the production practices involved in mumu processing are based on art rather than scientific knowledge, and thus vary from one person to another. This translates to variable quality characteristics.

Maize, the preferred cereal for тити processing, is used worldwide and constitutes one of the staple food commodities in Nigeria [3, 4, 5, 6, 7]. Processing of maize into traditional food products such as mumu is primarily meant to add variety to the diet and improve upon the utilization of maize in the country. However, it has been reported that traditionally processed products (such as mumu) have not been well accepted due to inadequate hygienic practices during and after processing, variable sensory quality attributes and unattractive presentation [7, 8]. Like most cereal-based foods, mumu is a good source of carbohydrates, but low in protein and fat $[9,10,11]$. This makes the product nutritionally deficient. Rising nutritional awareness of today's consumers continue to decrease the acceptance of such products. Mumu as a food product has great potentials. Мumu flour can be supplemented to improve upon its nutritional value. It can also be used as a base for food product development - with particular applications in cooked paste products - in soups as thickening agents, and in water with ginger 
added as beverages [12]. However, based on the above reasons, the product has been underutilized [2].

Characterization of traditional maize processing methods and the quality of the maize grains used is one way for further improvement upon the utilization, quality and acceptance of the products. Furthermore, in the face of increasing nutritional awareness among Nigerians, there is need to also improve on the nutritional quality of traditional cereal-based foods such as mumu. However, it has been stated that no significant improvement on any type of food product can be achieved without consideration of the traditional technology involved [13].

This paper presents the results of a survey on the traditional production techniques, handling and uses of mumu. The objective is to document such baseline information needed to provide guidelines for upgrading the production and the quality attributes of the product.

\section{MATERIALS AND METHODS}

A well-structured questionnaire was used to interview one hundred and fifteen (115) processors of mumu on methods of production and utilization of the product. A total of six (6) out of twelve (12) Tiv-speaking local government areas of Benue state - where тити is most consumed - were covered, namely; Makurdi, Gwer, Gwer-West, Gboko, Vandeikya and Kwande.

The questionnaire was personally administered to processors who also market the product in each of the two most popular markets in the selected local government areas. Processors were individually interviewed on the processing, desirable quality attributes and utilization of mumu. The data collected was subjected to statistical analysis in accordance with established methods $[14,15]$.

\section{RESULTS}

\section{Traditional mumu processing methods}

There exist variations in the procedure adopted for traditional methods of mumu processing. The individual unit operations include cleaning (sorting, winnowing, washing), sprinkling with water, steeping the grains, parboiling, roasting and milling. Apart from roasting the grains and milling into a meal, preliminary operations such as parboiling, steeping and sprinkling with water are optional. Besides, there are no specifications among any of the processes. Three procedures were identified for traditional mumu processing. These include:

(i) Sprinkling - The grains are winnowed to remove chaff and sorted to remove visible stones and other foreign materials. They are then sprinkled with a little amount of water. This is followed by roasting and milling. 
(ii) Steeping - the grains are winnowed, sorted and steeped in water overnight. The steeped grains are dewatered to remove the steep water and allowed to drain for about 10 - 15 minutes. This is followed by roasting and milling.

(iii) Parboiling - This involves preliminary cleaning and washing of the grains followed by cooking of the grains in water for about one hour to soften the grains. The pre-cooked grains are then roasted and milled.

Figure 1 is a process flow sheet that provides information on unit operations employed in the three procedures that were identified for traditional mumu processing.

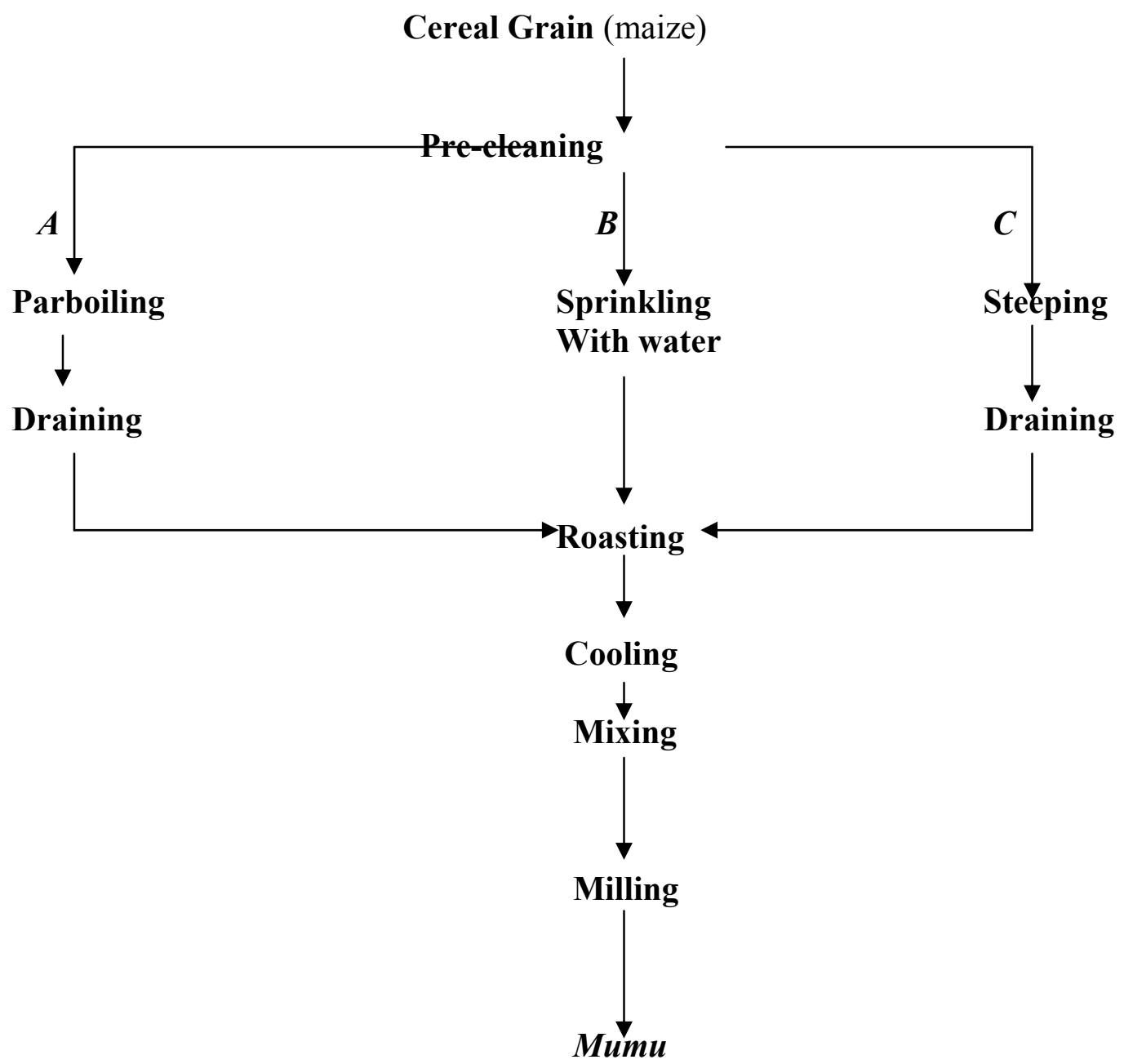

A, $\mathbf{B}$ and $\mathbf{C}=$ Procedures adopted for processing

Figure 1: Unit operations in the traditional processing of mumu 


\section{Indices of Traditional mumu Processing}

The results of indices of traditional mumu processing such as raw materials used, equipment used, desirable quality attributes and methods of processing are presented in Table 1. The results show that maize, the preferred cereal for mumu processing, is used by $83 \%$ of the respondents while $35 \%$ also use sorghum. No respondent reported the use of millet for mumu processing. Results also show that $70 \%$ of the respondents indicated that the most important desirable quality of mumu is its characteristic flavour. Results show that there were no significant differences $(\mathrm{P} \leq 0.05)$ between the number of respondents that parboil $(52 \%)$ and those that sprinkle $(43 \%)$ the grains as a preprocess operation. $100 \%$ of respondents indicated the use of earthenware pans as the equipment for roasting, while $75 \%$ of the interviewed processors utilize the stone mill for milling.

\section{Age, Sex and Educational Level of mumu processors/sellers}

Results of age distribution among processors indicate that only $4.35 \%(<25$ years $)$ young men and women, of those interviewed, responded positively to mumu processing. The age distribution of most processors ranged from 36 years and above (Table 2). This represents about $60 \%$ of those interviewed. It would appear therefore that it is mostly the elderly persons who carry out mumu processing. It may also be that only the aged people appreciate тити in terms of processing and handling, while the younger ones have little or no interest. Table 2 also shows that $92 \%$ of mumu processors are females. This seems to suggest that men consider the processing and sale of mumu to be a female affair. Results on educational level of mumu processors and sellers as shown in Table 2 indicate that $26 \%$ of them had only primary education while $49 \%$ had no formal education. This shows that most processors were of low educational level.

\section{Mode of utilization of mumu}

Most people (95\%) interviewed indicated that they consume mumu reconstituted in cold water in the afternoon (Table 3). Survey results as shown in Table 3 also indicate that sugar is most commonly employed for taste. The results of respondents $(100 \%)$ further show that тити is consumed by both adults and children. 


\section{DISCUSSION}

\section{Traditional mumu processing methods}

The three traditional methods of mumu processing are as shown in Figure 1 and Table 1 .

\section{Sprinkling}

This procedure involves adding a little amount of water to the grains and moistening it after cleaning (winnowing and hand picking of stones and foreign matter), without washing before roasting. It is the fastest method of producing mumu. Survey results indicated that many processors $(43 \%)$ adopt this procedure. However, this method is not recommendable because it does not take into cognizance, the fact that over floats and immature or decayed grains, which would have been removed during washing, could be left in the product. The cleaning operation is manually done and consists mainly of winnowing - to remove residual chaff in the grain - and hand-picking of visible stones and any other foreign matter in the grain. No machine sorting and grading of the raw materials is undertaken. This means that where the grains are directly milled following manual cleaning and hand picking of stones and foreign matter, fine sand particles, foreign grain particles, as well as immature and/or diseased grains may be included in the product. These can negatively affect the final product quality characteristics such as the colour, flavour and texture. Furthermore, the process does not allow the grains to be conditioned for the roasting process for faster temperature penetration and uniform colour development during roasting.

\section{Steeping}

The steeping operation as done for mumu processing is carried out using simple equipments such as basins, into which the grains are soaked overnight. Following this, they are removed from the steep water and washed before roasting. Very few of the processors $(4 \%)$ interviewed indicated that they steep the grains before roasting to produce тити (Table 1). Scientifically speaking, this ought to have been an important processing operation that all processors should adopt. This is because the steeping operation would further improve on the cleaning process as over floats and chaff would be discarded before further processing, unlike in the sprinkling process where this is not possible. Steeping would be a recommended process before further processing as a way of improving the cleaning operation, as well as obtaining higher quality products. This is because during steeping, certain physical and biochemical changes occur, such as swelling of grains, degradation of soluble carbohydrates and removal of some pigments, micro-organisms and bitter substances from the grains [16]. Furthermore, steeping has been reported to improve the nutritive value of beans in terms of mineral levels, and is recommended for cereals [17]. 


\section{Parboiling}

The traditional parboiling operation employed for mumu processing is achieved in cooking pots at boiling water for variable periods, usually not less than one hour, using firewood as the energy source. The process is usually preceded by thorough cleaning/washing. Parboiling is the most adopted method with $52.17 \%$ of those interviewed utilizing this method compared to $43.48 \%$ for sprinkling and $4.35 \%$ for steeping. This is a good indication. It should be noted that parboiling as employed in mumu processing, is a wet cooking operation. Generally, cereal grains are cooked to improve their eating quality, digestibility and the availability of nutrients which are present in them [12]. Cooking is also intended to improve the palatability of the food making it more appetizing [18]. Cooking with water or moist heat tends to soften and breakdown indigestible fibres, generally increasing digestibility of nutrients and phytochemicals $[12,19]$. During wet cooking, water dissolves vitamins from the bran and carries them into the endosperm [7]. In maize, wet cooking process destroys the phytate and releases bound niacin, making it more available [3]. Water cooking also makes the product more resistant to rancidity [7]. In addition, cooking pre-gelatinizes the grain and further enhances the roasting designed to impart desirable flavour and colour of the final product. Therefore, processed mumu, following pre-cooking (parboiling), has greater potential for better quality.

\section{Roasting}

Roasting is the main operation in the production of mumu. Roasting of maize is a popular operation and has been used to produce many maize products such as "corn nuts", "Aadun" "Dankuwa", "Guguru' and Elekute [5, 7, 20]. Traditional roasting of grains is used primarily to enhance flavour, but other benefits include reduction of anti-nutritional factors and extension of storage life [21, 22, 23, 24]. Traditional processors interviewed revealed that specially constructed earthenware pans and aluminium frying pans (usual household equipment) are the equipment employed for the roasting process. None of the processors employed responded positively to the use of a modern roaster or air-oven. Use of earthenware pans and aluminium frying pans make the control of heat generated very difficult. Subsequently, it is difficult to efficiently roast the grains to achieve the desired uniform quality attributes of тити flavour and golden-brown colour. The use of mechanically controlled roasters such as the gari fryer for small-scale processors, would probably improve on the efficiency of production [25]. It is noteworthy that the initial cost of the improved gari fryer could be relatively high. However, the advantages of improved production efficiency cannot be overemphasized.

\section{Milling}

After roasting to the desired flavour and colour, the product is milled into mumu meal. Milling is predominantly $(75 \%)$ done with the aid of the traditional stone mill particularly in the remote localities - while processors $(40 \%)$ in urban centres like 
Makurdi, use electrically operated and diesel powered disc-attrition mills. Since most processors interviewed were from rural areas where electrically-powered mills are not available for use, results indicate the use of the stone mill as the predominant milling equipment. Improved milling machines such as the hammer mill of different sizes and capacities are available and could be employed to improve on the milling efficiency [25]. Final product quality is determined by visual/manual inspection. During milling, flavour enhancers such as roasted groundnuts and/or sesame seeds may be introduced.

\section{Nutritional potentials of mumu}

The traditional practice of adding oilseeds such as groundnut and sesame seed during the milling process to enhance тити flavour provides room for improvement on its protein quality. Protein deficiency is still a major problem in Nigeria and in Africa particularly among the low income groups [26]. In Nigeria, this problem has become prevalent due to the faltering economy, which has led to declining import of costly protein-rich foods. Local production of protein-rich foods has also been low, a condition worsened by the low purchasing power of the people [26]. A United Nations Development Project (UNDP) report indicates that about one million Nigerians may die from protein deficiency by the year 2010 [27]. The need, therefore, to look inwards for inexpensive quality protein foods cannot be overemphasized.

Oilseeds such as Soya beans are known to be good sources of the essential amino acids, lysine and tryptophan, which are limiting in maize. Maize proteins on the other hand are good sources of methionine, an essential amino acid, limiting in soya beans. When combined, they complement each other with their respective limited amino acids. The quality of a protein is judged by the balance of essential amino acids present. Thus, combining a cereal like maize with an oilseed such as Soya beans results into a product that is nutritionally better than either ingredient alone [23]. Similarly, groundnuts, though low in lysine, when compared to Soya beans are also recognized as a valuable protein supplement in cereal foods [7]. Both Soya beans and groundnuts are widely grown and consumed in Nigeria. Groundnuts have generally been well accepted and are eaten in various ways. They are roasted or cooked and eaten as snacks. They may also be roasted, milled and blended as soup thickeners/spices/condiment and - as indicated above - are already employed as a flavour enhancer in mumu processing. The use of Soya beans as food in Nigeria has also been on the increase. Several technologies have been developed and are being employed to improve upon the utilization of Soya beans in Nigeria [28]. Thus, incorporation of Soya beans or groundnuts directly as a protein containing material as food falls within the domestic eating habits and purchasing power of the target population.

The present practice where small quantities of roasted groundnut/sesame seeds are added to maize grains as flavour enhancers, does not imply that mumu is nutritionally supplemented. This is because the quantities of the added flavour enhancers are too 
small to make significant impact on the nutritional quality of the product. Respondents indicated that only about a handful or one-tenth equivalent of maize is used as groundnut or sesame seeds for flavour improvement. The amount, however, varies from one processor to another. Since there is an already existing practice of adding oilseeds to mumu, their inclusion for the purpose of improving upon its protein quality should not impair the acceptability of the product. The need to improve on the nutritional quality of тити requires further research into the proper addition of the above mentioned flavour enhancers which have the potential to improve on the nutritional quality of the final product as indicated previously.

\section{Indices of Traditional mumu Processing}

Table 1 shows some of the indices of mumu processing. Survey results showed that maize is the significantly $(83 \%)$ preferred raw cereal grain for mumu. Sorghum was the next preferred (35\%) cereal for the production of muтu. Even though it was noted that millet could equally be used by those interviewed, none of them indicated ever using it to produce тити. The choice of maize over the other cereals is due to the characteristic mumu flavour, which it produces upon roasting. It will be noted that amongst the desirable quality attributes, flavour is significantly (70\%) preferred to both colour $(25 \%)$ and texture $(20 \%)$. It was also noted that while sorghum equally produced the desired golden-brown colour, it lacked the preferred flavour of roasted maize. Roasted maize flavour may thus be the characteristic mumu flavour, which is the major quality criterion. The emphasis on the flavour of mumu calls for a careful examination of the kind of supplement, which could be added to enrich the product. Adverse change in the flavour of the product may lead to reduced acceptance. There is, however, a need to supplement тити since it is completely a maize food product, which is deficient both in protein quantity and quality $[6,7,8]$. This study recommends the use of Soya beans and/or groundnut for supplementation of maize in the order to improve on its protein quality - since these sources already form part of the diet of the people.

\section{Mode of utilization of mumu}

Survey results (Table 3) indicate that mumu is a ready-to-eat food product, which is reconstituted in cold water and eaten. $100 \%$ of respondents indicated that the product is suitable for both adults and children. This means that if enriched by supplementation and properly processed and handled, mити could serve as a vehicle to improve the nutritional status of all categories of the population. The survey result also showed that most respondents $(96 \%)$ consume mumu in the afternoon. Since it is reconstituted in cold water, it serves as a refreshing and thirst quenching drink in the tropical climates. About $4 \%$ of respondents indicated reconstituting mumu in hot water. This means that the product can be utilized as a breakfast food item in the same way as the likes of oatmeal and cornmeal. 


\section{CONCLUSIONS}

This study has shown that maize is the preferred raw material for mumu processing. The study also indicates that more than $70 \%$ of mumu processors, $92 \%$ females, mostly $(>60 \%)$ from the age of 36 years and above are not well educated and therefore, ill-equipped to appreciate modern methods of food hygiene, handling and processing. Since there has been no scientific study of mumu processing technology, the production and utilization has not gone beyond the local level. The processing operations are poorly defined. Efficiency of production is low due to lack of appropriate processing equipment.

The study further indicates that тити as a food product - has great potentials. It can be supplemented to improve upon its nutritional status. Standardization of processing conditions for reproducibility and uniformity of quality attributes is one way of upgrading it. There is also need to develop suitable packages for proper presentation of the product in order to improve upon consumer appeal and patronage; as well as raising awareness to involve young, educated men and women who are better equipped to understand and appreciate the use of modern food processing, in order to improve on the production, handling and utilization of the product. 


\section{Table 1:}

Indices* of traditional mumu processing

\begin{tabular}{llc}
\hline Criteria & No. of Respondents & Percentage \\
\hline Cereals Used: & $\mathbf{9 5}$ & $\mathbf{8 2 . 6 1}^{\mathrm{a}}$ \\
Maize & $\mathbf{4 0}$ & $\mathbf{3 4 . 7 \mathbf { b } ^ { \mathbf { b } }}$ \\
Sorghum & - & - \\
Millet & & \\
Equipment Used: & 115 & $100^{\mathrm{a}}$ \\
Roasting: & Nil & $0^{\mathrm{b}}$ \\
Earthen ware pans & & \\
Air-oven & & \\
& 75 & $65.22^{\mathrm{a}}$ \\
Milling: & 40 & $34.78^{\mathrm{b}}$ \\
Usual household (stone mill) & & \\
Electric/Diesel powered mill & $\mathbf{2 5}$ & $\mathbf{2 1 . 7 4 ^ { \mathrm { a } }}$ \\
Desirable quality attributes: & 70 & $60.86^{\mathrm{b}}$ \\
Colour & 20 & $17.39^{\mathrm{a}}$ \\
Flavour & & \\
Texture & & \\
Processing Procedure: & 60 & $52.17^{\mathrm{a}}$ \\
Parboiling & 5 & $4.35^{\mathrm{b}}$ \\
Steeping & 50 & $43.48^{\mathrm{a}}$ \\
Sprinkling & & \\
& & \\
\hline
\end{tabular}

*Any two values in the percentage column not followed by the same superscript are significantly $(\mathrm{P} \leq 0.05)$ different. 


\section{Table 2:}

Age distribution, sex and educational level of mumu processors

\begin{tabular}{lllllllll}
\hline $\begin{array}{l}\text { Age } \\
\text { (Years) }\end{array}$ & $\begin{array}{l}\text { Number of } \\
\text { Respondents }\end{array}$ & $\begin{array}{l}\text { Percentage } \\
(\%) \text { of } \\
\text { respondents }\end{array}$ & $\begin{array}{l}\text { Number } \\
\text { of }\end{array}$ & $\begin{array}{l}\text { Females } \\
\text { of } \\
\text { Males }\end{array}$ & $\begin{array}{l}\text { Mducational } \\
\text { Respondents }\end{array}$ & Level & of \\
\hline 25 & 5 & 4.35 & 5 & 0 & 5 & 0 & 0 & $2^{0}$ \\
\hline $26-35$ & 40 & 26.96 & 31 & 9 & 15 & 10 & 15 & 0 \\
$36-45$ & 45 & 39.13 & 45 & 0 & 10 & 0 & 5 & 30 \\
$>45$ & 25 & 21.74 & 25 & 0 & 0 & 0 & 0 & 25 \\
$\begin{array}{l}\text { Total } \\
\begin{array}{l}\text { Percentage } \\
\text { of total }\end{array}\end{array}$ & 115 & 100 & 106 & 9 & 30 & 10 & 20 & 55 \\
\hline
\end{tabular}

Key:

$1^{0}=$ Primary education

$2^{0}=$ Secondary education

$3^{0}=$ Higher education

$\mathrm{NE}=$ No formal education 


\section{Table 3:}

Mode of Utilisation* of mumu

Mode of utilization

Time of consumption:

Morning

Afternoon

Evening

Ingredients of reconstitution:

Sugar

Honey

$$
\text { No. of respondents }
$$

110

4.34

95.65

21.74

Percentage

86.96

34.78

\section{Medium of reconstitution:}

Hot water

5

4.34

Cold water

\section{Category of consumers:}

Adults only

Children only

Adults and Children

115

100

*Total number interviewed $=115$ 


\section{REFERENCES}

1. Oguntunde AO Traditional Convenience Foods from major Nigeria Cereal Grains. Nigerian Food Journal 1998; 7: 58 - 66.

2. Manyam NN A survey of Indigenous Food Commodities Benue State and Methods of their Processing and Preparation. Makurdi, 1987.

3. Rooney LW and SO Serna - Saldivar Food uses of whole Corn and dry milled fractions. In: Stanley, A. Watson and Paul, E. Ramstad (Eds).Corn Chemistry and Technology, U. S. A. American Association of Cereal Chemists, 1987: 399 429.

4. Fakorede MAB, Alofe CO and SK Kim Maize: improvement, Production and utilization. Maize Association of Nigeria. Nigeria 1983: i-iii.

5. Okoruwa AE Utilization and Processing of Maize. IITA Research Guide 35. International Institute for Tropical Agriculture, 1995.

6. Downswell CR, Palimal RL and RP Cantrell Maize in the Third World. Westview Press, New York, U.S.A. 1996: 1, 21 - 24.

7. Ihekoronye AI and PO Ngoddy Integrated Food Science and Technology for the Tropics. Macmillan Publishers Ltd., London 1985: 236-258.

8. Nout MJR Upgrading Traditional Biotechnology processes. Provisional Report No. 20. In: proceedings of International Foundation for Science and United Nations University (IFS/UNU) Workshop: Development of Indigenous Fermented Foods and Food Tecnology in Africa. 1985: 91 - 99.

9. Oyenuga VA Nigeria's Foods and Feeding stuffs: Their Chemistry and Nutritive values. Ibadan University Press, Ibadan, 1968. 
10. Banigo EB and MA Akpapunam Physico-chemical and Nutritional Evaluation of Protein - enriched Fermented Maize Flour. Nigerian Food Journal, 1987; 5: $30-36$.

11. Omueti O and IO Morton Development, Acceptability Nutritional and Physical Characteristics of Protein improved Nigeria Abari (Maize Meal) prepared from Soya and Maize flours. International Journal of Food and Nutrition , 1996; 47(5): $369-375$.

12. Kordylas JM Processing and Preservation of Tropical and Sub-tropical Foods. Macmillan Education Ltd. London, 1991; 49-73.

13. Sefa-Dedeh $\mathbf{S}$ Harnessing Traditional Food Technology. In: proceedings of a Workshop. Harnessing Traditional Food Technology for Development. Kellogg International Fellowship Programme in Food Systems. 1989; 114 - 135.

14. Steel RG and JH Torrie Principles and Procedures of Statistics. McGraw hill Book Co. New York, 1981.

15. Microsoft Corporation SPSS 10.0 for Windows. SPSS inc. Redmond, Washington, 1999.

16. Owuama IC Brewing beer with sorghum. J. Inst. Brewing, 1998; 105: 23-24.

17. Youssef MM, Shekib LA and HM Ziena Effect of dehulling, soaking and germination on chemical composition, mineral elements and protein patterns of faba beans. Food Chem, 1987; 23:127-129.

18. Rosenthal A J Cooking. In: Hui, Y. H.( ed.) Encyclopedia of Food Science and Technology. New York, 1992; 3:1227-1232.

19. Slavin JL, Jacobs D and L Marquart Grain processing and nutrition. Critical Reviews in Biotechnology. 2001; 21: 49-66.

20. Ayatse JO, Eka OU and ET Ifon Chemical evaluation of the effect of roasting on the nutritive value of maize. Food Chemistry. 1983; 12: 135-147. 
21. D'Appolonia BL Use of untreated and roasted navy beans in bread baking. Cereal Chem. 1978;3: 898-907.

22. .Khan N Zaman R and M Elahi Effect of processing on Phytic acid content of bengal grams ( $\underline{\text { Cicer }} \underline{\text { arietinum }})$ products. J. Agric. Food Chem. 54 : 153-154.

23. Gahlawa, $\mathbf{P}$ and $\mathbf{S}$ Seghal Phytic acid, saponins, and polyphenols in weaning Foods prepared from oven-heated green gram and cereals. Cereal Chem. 69: 463464.

24. Huffman SL and LH Martin First feedings: Optimal feeding of infants and toddlers. Nutr. Res. 1994; 14: 127-159.

25. Kent NL Technical Compendium on composite Flours: Technologies Available. FAO/UN/Economic Commission for Africa, Addis Ababa, 1985.

26. Osho SM and K Dashiell Expanding Soya bean production, processing and utilization in Africa. Post harvest Systems. 1997; Online at http://www.iita.org

27. Attah V Report of a workshop on conflict resolution and management. November 11 edn. Daily trust. 2002; Online at http://www.allafrica.com

28. Osho SM Methods for the dissemination of food processing technologies. The Soya bean example in Nigeria. 1998; Online at http://www.ishs.org 